\title{
RISK ASSESSMENT OF PILING WORK FOR MASS RAPID TRANSIT (MRT) CONSTRUCTION PROJECT
}

\author{
Asmalia Che AHMAD ${ }^{I}$, Izatul Farrita Mohd KAMAR ${ }^{2}$, Abdul Muhaimin Ab WAHID', \\ Muhamad Fazreen Niza Shah ISMAIL ${ }^{I}$
}

DOI: 10.21163/GT_2019.141.37

\begin{abstract}
:
This study focuses on the piling works of Mass Rapid Transit (MRT) line 1 construction project along Sungai Buloh Station to Kajang Station in Malaysia, considering that piling work is one of the high risk construction activities. This study utilizes risk assessment tool using Hazard Identification, Risk Assessment \& Risk Control (HIRARC) to create safe construction workplace. The hazard identification is a process of examination work area and task inherent to piling activities. The risk assessment of piling works calculated using likelihood and severity. Based on the hazard identification and risk assessment results, control measures or risk control are taken into action. The risk assessment sheets as the research instrument tool were filled by 30 construction professionals and safety practitioners i.e. safety officers, safety supervisors, site engineers and site supervisors. The results indicated that there were seven hazards that associated with piling works. One of the hazards which caused structure collapse during test pile activity was assessed as the extreme risk. Other six hazards were assessed as high risk. The total 27 risk control measures were resolved in order to eliminate and reduce hazards as well as prevent accident during piling work at the MRT construction project.
\end{abstract}

Key-words: Construction, Mass Rapid Transit (MRT), Piling Work, Risk Assessment.

\section{INTRODUCTION}

Mass Rapid Transit (MRT) is one of the prime transportation infrastructure projects in Malaysia. MRT construction consists of three MRT urban rail lines. MRT line 1 connects Sungai Buloh to Kajang which include of 31 stations with the rail span of $51 \mathrm{~km}$. MRT line 2 connects Sungai Buluh to Putrajaya which consist of 40 stations that are spread along the route. MRT line 3 is the Circle Line that loops around hotspot city area such as Kuala Lumpur City Center (KLCC) covering $20 \mathrm{~km}$ radius of Bukit Bintang, Damansara and Sentul. For MRT line 1 Sungai Buloh-Kajang, the first phase of construction from Sungai Buloh to Semantan has been newly operational at the end of 2016. The second phase of construction, from Semantan to Kajang is fully operational for public passengers by July 2017, allowing trains to run the entire alignment. Each train set serving the line have four cars, allowing a total capacity of 1200 passengers. The daily ridership is estimated to be about 400000 passengers. The fastest trains run at a frequency of 3.3 minutes (MyMRT, 2017).

1 Universiti Teknologi MARA, Faculty of Architecture Planning and Surveying, Seri Iskandar Campus, Seri Iskandar, 32610,Perak, Malaysia.asmalia809@uitm.edu.my; abdul982@uitm.edu.my; fazreen33@gmail.com;

2 Universiti Teknologi MARA, Centre of Postgraduate Studies, Seri Iskandar Campus, Seri Iskandar, 32610,Perak, Malaysia.izatu739@uitm.edu.my,

3 Universiti Teknologi MARA, Green Safe Cities (GreSafe) Research Group, Shah Alam Campus, 40450, Selangor, Malaysia. 
MRT construction is one of the mega project with strict regulation regarding safety, health and environmental. However, accidents could happen unpredictably and mostly end with major injuries, fatal and costly massive losses (Albert et al., 2014; Kamar \& Ahmad, 2016). Quite a number major accidents related to MRT construction have been reported which caused fatality and injured cases. In large-scale construction projects, the accident rate is higher than that of common construction projects due to the involvement of many workers, many large and heavy plants, various materials, complex construction operation, multi-interface, and complex management activities (Guo et al., 2013). Construction of MRT project involved various construction activities that are hazardous such as piling in obstructed urban area, tunnel excavation with extensive underground services, construction works near uses public road and usage of high voltage electric for construction works

The prevention of construction accidents usually entails predicting future accident and their nature under given circumstances (Al-Kilani, 2011). Therefore, it is important to understand how these accidents and injuries are generated (Chi \& Han, 2013). Accident prediction is done through the risk management process which consists of identification of the hazard, calculation of the risk assessment and determining safe control measures (Health Safety Executive, 2006; Perry, 2003; Binnington, 2011). The aim of this study is to measure and control the risk for one of the critical construction activities in MRT Project which is piling works. The objectives of this study are to identify hazards during piling works, to assess the risk level of those hazards and to determine the risk control measures. The result of this study could benefit the contractor in order to reduce risk of piling works during MRT construction project. The methodology for this study has taken quantitative approach using a risk assessment sheet as the instrument tool.

\section{LITERATURE REVIEW}

\subsection{Risk Management}

Construction industry is well known with hazardous workplace and accident potential. There are five sequential dominos contributing to a construction accident i.e. (i) ancestry and social environment, (ii) fault of a person, (iii) unsafe act and mechanical or physical hazards, (iv) accident and (v) injury (Chi \& Han, 2013; Ridley, 1990; Chong \& Low, 2014). Accidents lead to injuries or worst death, and that these accidents occurred when worker committed unsafe acts or there were direct mechanical or physical hazards related to the work (Ridley, 1990; Chong \& Low, 2014).

The prevention of construction accidents usually entails predicting future accidents and their nature under given circumstances (Al-Kilani, 2011). Risk management is an approach to - prevent accidents by early identification and suggesting appropriate control measures. Risk management refers to the practice of identifying potential hazard in advance, analyzing and evaluate the risk of those hazard and taking precautionary steps to reduce the risk (Health Safety Executive, 2006).

\subsection{HIRARC}

Hazard Identification, Risk Assessment and Risk Control (HIRARC) have become an essential tool in practice of planning, management and the operation of a basic of risk management and assessment (Perry, 2003). HIRARC was applied to recognize substandard act and working condition as list of hazards was developed and analyzed thus to take necessary corrective action. In line with that, Department of Safety and Health (DOSH) has highlighted HIRARC as important for identifying hazard, analyzing and assessing its 
associated risk and then applying the suitable control measures subsequently. The process of HIRARC is shown in Fig. 1.

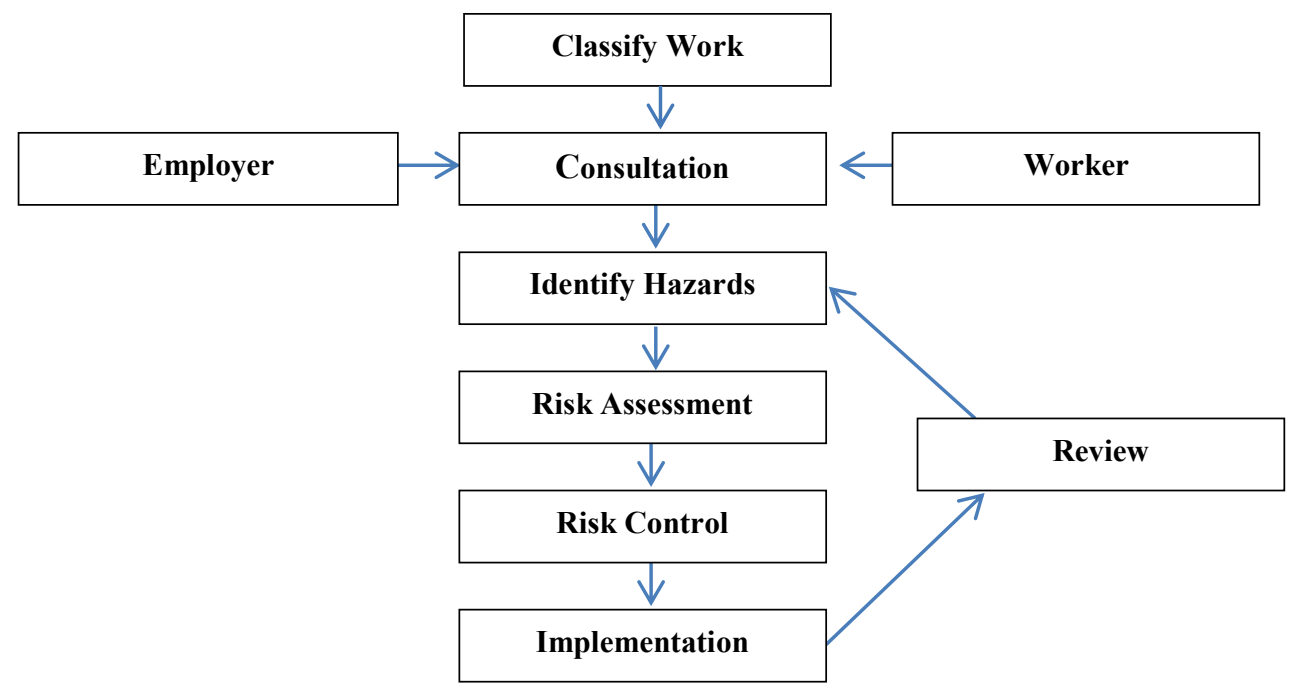

Fig. 1. Process of HIRARC.

\subsubsection{Hazard Identification}

Hazard is a dangerous condition substance that unavoidable of risk although have been able to be foreseen or predicted that lead to an accident (Goetsch, 2009). Hazard presents a potential to cause harm (Department of Occupational Safety and Health, Ministry of Human Resources Malaysia, 2008; Huges \& Ferrett, 2008). It is an indirect event or physical substance which possibly happens and cause harm to people, property, processes or environment (Huges \& Ferrett, 2008; Stefanescu et al., 2008).

Hazard identification is the process of examining each work area and work task for the purpose of identifying all the hazards which are inherent in the job (Welfare Health \& Safety Unit, 2015).

In the process of recognizing hazards, attention should be given to hazard origins. Hazards originate from (i) construction workplace itself i.e. location, layout, condition and accessibility, (ii) the design concerning the work, (iii) tasks concern with height or depth, (iv) hazardous materials i.e. handling, usage, storing and transportation, (v) systems of work (vi) plant and equipment i.e. installation, erection, commissioning, use, repair, maintenance, dismantling, transport, storage and disposal, (vii) manual handling and (viii) physical working environment i.e. objects or structures falling, electric shock, immersion or engulfment, fire or explosion, noise, heat, cold, vibration, slips, trips, falls, confined space and contaminated atmosphere (Binnington, 2011).

It is important to identify the hazard as it is the root cause of accident (Department of Occupational Safety and Health, Ministry of Human Resources Malaysia, 2008; Hamid et al., 2003). Another significance of hazard identification is that it can be used as an improvement tools for inspections, supervisions, training, better definition of responsibilities, and pre-job planning by supervisors (Ridley, 1990; Welfare Health \& Safety Unit, 2015; Hamid et al., 2003). 


\subsubsection{Risk Assessment}

In construction project context, risk is an event that, if it occurs, adversely affects the achievement of the project objectives (Carter and Smith, 2006). Risk a measurement to evaluate hazard. Determining the risk value of construction hazards depends on the likelihood and severity. Risk value is calculated by multiplying the likelihood of the hazard with severity occurrence of the hazard with the formula (Department of Occupational Safety and Health, Ministry of Human Resources Malaysia, 2008):

$$
\text { Risk }(\mathrm{R})=\text { Likelihood }(\mathrm{L}) \times \text { Severity }(\mathrm{S})
$$

Risk assessment is the overall process of risk analysis (identification and estimation) and risk evaluation (measurement and tolerance) (Campbell, 2008). In other words, risk assessment can be defined as the process of assessing the risks associated with each of the construction hazards identified. The assessment could be done in structured discussion, consultation or formal meetings (Work Safe Victoria, 2007).

Risk assessment contained information of identified hazards that could periodically review or updated as construction work progresses (Hinze and Raboud, 1988). Additionally, the risk assessment need to be done systematically in order the person in charge of the construction site i.e. project manager and safety officer could resolve whether they have taken adequate precautions or should do more control measures in order to prevent harm (Health Safety Executive, 2006).

\subsubsection{Risk Matrix}

Risk matrix is used as basis to risk assessment. Risk matrix is the combination of likelihood and consequence or severity range that gives an estimate of risk or risk level. Construction of a Risk Matrix Level starts by establishing how the matrix is intended to be used (Ahmad et al., 2016). Initial decision that has to be made is to define the risk acceptability or tolerability criteria for the organization using the matrix.

Table 1 contains the value of Risk (R) on hazard that equals to multiplication of Likelihood (L) and Severity (S) of the hazard. Table 2 shows the indication of Risk Matrix Level that was categorized as Low, Medium, High and Extreme (Department of Occupational Safety and Health, Ministry of Human Resources Malaysia, 2008).

Table 1. Risk is the multiplication of Likelihood and Severity

\begin{tabular}{llllll}
\hline \multirow{2}{*}{ Likelihood (L) } & \multicolumn{6}{c}{ Severity (S) } \\
\cline { 2 - 7 } & $\begin{array}{c}\text { Not Critical } \\
(1)\end{array}$ & $\begin{array}{c}\text { Low } \\
\text { Critical (2) }\end{array}$ & $\begin{array}{c}\text { Moderate } \\
(3)\end{array}$ & Critical (4) & $\begin{array}{c}\text { Very } \\
\text { critical (5) }\end{array}$ \\
\hline Never (1) & 1 & 2 & 3 & 4 & 5 \\
\hline Rare (2) & 2 & 4 & 6 & 8 & 10 \\
\hline Sometimes (3) & 3 & 6 & 9 & 12 & 15 \\
\hline Frequently (4) & 4 & 8 & 12 & 16 & 20 \\
\hline Almost Certain(5) & 5 & 10 & 15 & 20 & 25 \\
\hline
\end{tabular}

Table 2. Legend on Risk Matrix Level

\begin{tabular}{c}
\hline Legend for Risk Matrix Level \\
\hline Low : 1.00 to 2.00 \\
\hline Medium: 3.00 to 6.00 \\
\hline High: 7.00 to 12.00 \\
\hline
\end{tabular}




\subsubsection{Risk Control}

Based on the hazard identification and risk assessment which being implemented at the early stage, the controlling measure or risk control can be initiated to ensure the safety of construction worker and workplace. Risk control is the elimination or inactivation of a hazard in a manner such that the hazard does not pose a risk to workers who have to enter into an area or work on equipment of the scheduled work (Department of Occupational Safety and Health, Ministry of Human Resources Malaysia, 2008). Risk control implies making a move to dispose dangers as sensibly practicable which will eliminate or reduce a hazard likewise dispense any dangers connected to the hazard (Albert et al., 2014).

Appropriate risk control involves (i) identifying options for controls, (ii) considering the possibility of excellently eliminating or reducing risk and (iii) applying the selected option (Ahmad et al., 2016). Selecting option of a control measures involves three stages which comprise (i) evaluating and selecting short and long term controls, (ii) implementing short-term measures to protect workers until permanent control can be put in place and lastly (iii) implementing long term controls when reasonably practicable (Department of Occupational Safety and Health, Ministry of Human Resources Malaysia, 2008).

The risk control stage involves evaluating effectiveness of risk control measures after defining the risk assessment and risk matrix. Table 3 shows the indicator for effectiveness level of the control measures introduce for the hazard.

Table 3. Indicator for risk control measures

\begin{tabular}{lll}
\hline \multicolumn{1}{c}{ RISK CONTROL MEASURES } & \multicolumn{2}{c}{ INDICATOR LEVEL } \\
\hline $\begin{array}{l}\text { Control measures exceeding industry standards and the best } \\
\text { practices. Loss potential is considered significantly reduced }\end{array}$ & Excellent & 3.10 to 4.00 \\
\hline $\begin{array}{l}\text { Control measures that are consistent with industry standards and } \\
\text { best practices. Loss potential is considered to be average }\end{array}$ & Good & 2.10 to 3.00 \\
\hline $\begin{array}{l}\text { Control measures that approach industry standards and best } \\
\text { practices, however deficiencies exist. Loss potential is considered }\end{array}$ & Fair & 1.10 to 2.00 \\
somewhat increased & & \\
\hline $\begin{array}{l}\text { A control measure has major deficiencies and does not approach } \\
\text { industry standards and best practices. Loss potential is considered } \\
\text { to be significantly increased. }\end{array}$ & & 0.00 to 1.00 \\
\hline
\end{tabular}

\section{RESEARCH METHODOLOGY}

The scope of study focuses on construction of MRT project. The case study encompasses piling works on construction of MRT line 1 from Sungai Buloh station to Kajang station. Fig. 2 shows the route map of MRT Line 1 Sungai Buloh to Kajang.

The types of collected data are primary and secondary data. Primary data entailed risk assessment involving construction professionals and safety practitioners of MRT project. Secondary data encompassed progress and safety reports of MRT project. Primary data were obtained from risk assessment sheets. The risk assessment sheet consist list of hazard identification, risk assessment and control measure as according to HIRARC process which tailored for the piling works at MRT construction site. Secondary data were extracted accordingly to develop the risk assessment sheet which present as the research instrument tool. 
40 risk assessment sheets were distributed to construction professionals and safety position of safety officers, safety supervisors, site engineers and site supervisors of MRT project. The respondents were asked to indicate rating on the risk assessment sheet. However, only 30 sheets were returned. The data from risk assessment sheets were analyzed using Statistical Package for the Social Science System (SPSS) and Microsoft Excel. The mean score were used to establish the rank for the risk matrix. The mean score was used to establish the rank for the risk matrix and indicator for control measures as perceived by the respondents. The mean analysis used is similar to previous empirical study on safety management of construction workplace (Fang et al., 2004) which solicited views from construction personnel (Lam et al., 2010).

\section{ANALYSIS AND RESULTS}

Table 4 shows the analysis and the findings of the study i.e. risk assessment for piling works at MRT construction site. There were seven 7 hazards identified for six activities that related to piling works which are, (i) structure collapse, (ii) unsecure load, (iii) machinery movement or mechanical failure, (iv) mixer truck movement, (v) heat or burn or harmful fume, (vi) chemical hazard and (vii) landslide or sheet pile topple. Five of the hazards identified were classified under safety, one hazard i.e. heat/burn/harmful fume was categorized under safety and health while chemical hazards during concrete work was classified under health hazard. Structure collapse during pile testing (risk matrix mean =12.76) was regarded as having extreme level of risk while other six hazards were considered as having high level risk. None of the hazard during piling work was assessed as medium or low risk.

The second highest level of hazard of piling works was landslide or sheet pile topple (risk matrix mean $=9.86$ ) during excavation of pile cap. The third highest level of hazard was the unsecure load/ mechanical failure (risk matrix mean $=9.67$ ) during lifting reinforcement and. The fourth highest level of hazard was machinery movement/mechanical failure (risk matrix mean $=9.06$ ) during machinery activities followed by mixer truck movement (risk matrix mean $=8.40$ ) during concrete work activities. Another two hazard ranked on sixth and seventh are heat/burn/harmful fume (risk matrix mean $=7.63$ ) during welding and oxy cutting of the pile and chemical hazard (risk matrix mean $=6.40$ ) during concrete work. All together 27 risk control measures had been discovered as action for the seven hazards identified during piling work at MRT construction site. All risk control measures were regarded as excellent i.e. mean of control measures more than 3.0 except for use of personal protective equipment (PPE) for chemical hazard during concrete work activities, which is indicated as good (mean of control measure $=2.90$ ).

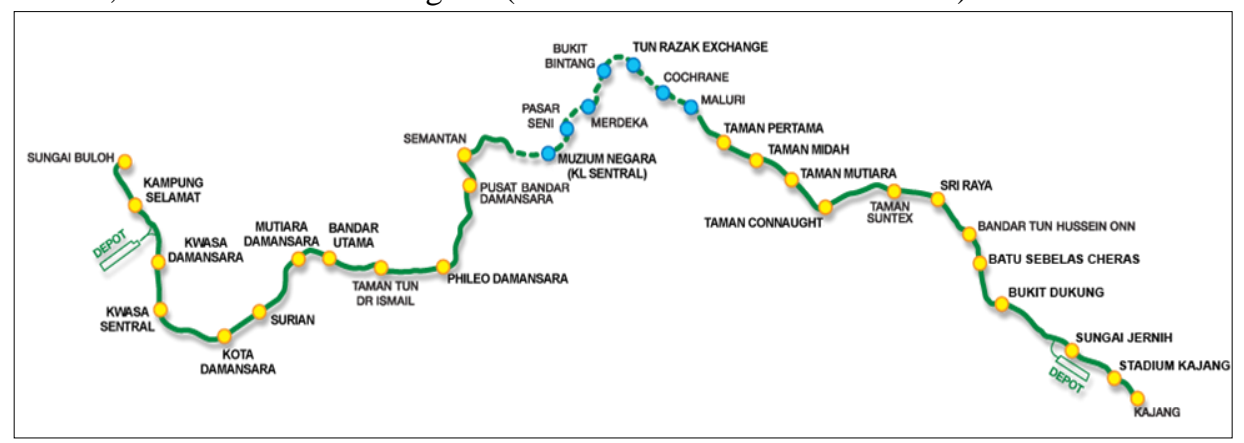

Fig. 2. Route map for MRT Line 1 Sungai Buloh to Kajang. 
Table 4. The summary of Hazard Identification, Risk Assessment and Risk Control (HIRARC) for piling works in MRT construction project with Control Measures Indicator: Excellent.

\begin{tabular}{|c|c|c|c|c|c|c|c|c|c|}
\hline & \multirow{2}{*}{$\begin{array}{c}\text { Activitie } \\
\text { s } \\
\text { Piling } \\
\text { Works }\end{array}$} & \multicolumn{2}{|c|}{ Hazard Identification } & \multicolumn{3}{|c|}{ Risk Assessment } & & \multirow[b]{2}{*}{$\begin{array}{c}\text { Control } \\
\text { Measures }\end{array}$} & \multirow[b]{2}{*}{$\begin{array}{c}\text { Control } \\
\text { Measure } \\
\text { s Mean }\end{array}$} \\
\hline & & $\begin{array}{c}\text { Hazard } \\
\text { Identificatio } \\
n\end{array}$ & $\begin{array}{c}\text { Hazard } \\
\text { Classific } \\
\text { ation }\end{array}$ & $\begin{array}{l}\text { Risk } \\
\text { Matri } \\
\mathrm{x} \\
\text { Mean } \\
\end{array}$ & $\begin{array}{c}\text { Risk } \\
\text { Matrix } \\
\text { Level }\end{array}$ & $\begin{array}{c}\text { Risk } \\
\text { Ran } \\
\mathrm{k}\end{array}$ & & & \\
\hline \multirow[t]{4}{*}{1} & \multirow[t]{4}{*}{ Test Pile } & \multirow[t]{4}{*}{$\begin{array}{l}\text { Structure } \\
\text { collapse }\end{array}$} & \multirow[t]{4}{*}{ Safety } & \multirow[t]{4}{*}{12.76} & \multirow[t]{4}{*}{ Extreme } & \multirow[t]{4}{*}{1} & $\mathrm{i}$ & $\begin{array}{l}\text { Close } \\
\text { supervision } \\
\text { by assigned } \\
\text { personnel } \\
\end{array}$ & 3.63 \\
\hline & & & & & & & $\begin{array}{l}\mathrm{i} \\
\mathrm{i}\end{array}$ & $\begin{array}{l}\text { Ensure } \\
\text { suitable } \\
\text { foundation } \\
\text { for } \\
\text { temporary } \\
\text { works }\end{array}$ & 3.16 \\
\hline & & & & & & & $\begin{array}{l}\mathrm{i} \\
\mathrm{i} \\
\mathrm{i}\end{array}$ & $\begin{array}{l}\text { Inspection } \\
\text { of physical } \\
\text { load test } \\
\text { material }\end{array}$ & 3.53 \\
\hline & & & & & & & $\begin{array}{l}\mathrm{i} \\
\mathrm{v}\end{array}$ & $\begin{array}{l}\text { Do not } \\
\text { seating } \\
\text { under the } \\
\text { load test } \\
\text { border }\end{array}$ & 3.23 \\
\hline \multirow[t]{5}{*}{2} & \multirow{5}{*}{$\begin{array}{l}\text { Lifting } \\
\text { reinforce } \\
\text { ment and } \\
\text { casting }\end{array}$} & \multirow[t]{5}{*}{$\begin{array}{l}\text { Unsecure } \\
\text { load/mecha } \\
\text { nical failure }\end{array}$} & \multirow[t]{5}{*}{ Safety } & \multirow[t]{5}{*}{9.67} & \multirow[t]{5}{*}{ High } & \multirow[t]{5}{*}{3} & $\mathrm{i}$ & $\begin{array}{l}\text { Assign } \\
\text { competent } \\
\text { person }\end{array}$ & 3.53 \\
\hline & & & & & & & $\begin{array}{l}\mathrm{i} \\
\mathrm{i}\end{array}$ & $\begin{array}{l}\text { Using 'tag } \\
\text { line' during } \\
\text { lifting } \\
\text { work3.16 }\end{array}$ & 3.16 \\
\hline & & & & & & & $\begin{array}{l}\mathrm{i} \\
\mathrm{i} \\
\mathrm{i}\end{array}$ & $\begin{array}{l}\text { Carry out } \\
\text { physical } \\
\text { inspection } \\
\text { for lifting }\end{array}$ & 3.00 \\
\hline & & & & & & & $\begin{array}{l}\mathrm{i} \\
\mathrm{v}\end{array}$ & $\begin{array}{l}\text { Sling-do } \\
\text { not stand } \\
\text { under } \\
\text { suspension } \\
\text { load }\end{array}$ & 3.26 \\
\hline & & & & & & & $\mathrm{v}$ & $\begin{array}{l}\text { Appoint } \\
\text { banksman }\end{array}$ & 3.10 \\
\hline \multirow[t]{3}{*}{3} & \multirow[t]{3}{*}{$\begin{array}{l}\text { Machine } \\
\text { ry work }\end{array}$} & \multirow{3}{*}{$\begin{array}{l}\text { Machinery } \\
\text { movemen/m } \\
\text { echanical } \\
\text { failure }\end{array}$} & \multirow[t]{3}{*}{ Safety } & \multirow[t]{3}{*}{9.06} & \multirow[t]{3}{*}{ High } & \multirow[t]{3}{*}{4} & $\mathrm{i}$ & $\begin{array}{l}\text { Machinery } \\
\text { inspection }\end{array}$ & 3.30 \\
\hline & & & & & & & $\begin{array}{l}\mathrm{i} \\
\mathrm{i}\end{array}$ & $\begin{array}{l}\text { Supervision } \\
\text { during } \\
\text { movement }\end{array}$ & 3.46 \\
\hline & & & & & & & $\begin{array}{l}\mathrm{i} \\
\mathrm{i}\end{array}$ & $\begin{array}{l}\text { Competent } \\
\text { person }\end{array}$ & 3.53 \\
\hline
\end{tabular}




\begin{tabular}{|c|c|c|c|c|c|c|c|c|c|}
\hline & & & & & & & \multicolumn{3}{|l|}{ i } \\
\hline & & & & & & & $\begin{array}{l}\mathrm{i} \\
\mathrm{v}\end{array}$ & $\begin{array}{l}\text { Appoint } \\
\text { banksman }\end{array}$ & 3.40 \\
\hline \multirow[t]{3}{*}{4} & $\begin{array}{l}\text { Concrete } \\
\text { work }\end{array}$ & $\begin{array}{l}\text { Mixer truck } \\
\text { movement }\end{array}$ & Safety & 8.40 & High & 5 & $\mathrm{i}$ & $\begin{array}{l}\text { Provide } \\
\text { proper } \\
\text { access }\end{array}$ & 3.50 \\
\hline & & & & & & & $\begin{array}{l}\mathrm{i} \\
\mathrm{i}\end{array}$ & $\begin{array}{l}\text { Appoint } \\
\text { banksman }\end{array}$ & 3.80 \\
\hline & & & & & & & $\begin{array}{l}\mathrm{i} \\
\mathrm{i} \\
\mathrm{i}\end{array}$ & $\begin{array}{l}\text { Apply speed } \\
\text { limit }\end{array}$ & 3.36 \\
\hline \multirow[t]{5}{*}{5} & \multirow{5}{*}{$\begin{array}{l}\text { Welding } \\
\& \text { oxy } \\
\text { cutting }\end{array}$} & \multirow[t]{5}{*}{$\begin{array}{l}\text { Heat/burn/h } \\
\text { armful fume }\end{array}$} & \multirow[t]{5}{*}{$\begin{array}{l}\text { Safety \& } \\
\text { Health }\end{array}$} & \multirow[t]{5}{*}{7.63} & \multirow[t]{5}{*}{ High } & \multirow[t]{5}{*}{6} & $\mathrm{i}$ & $\begin{array}{l}\text { Obtain hot } \\
\text { work permit }\end{array}$ & 3.36 \\
\hline & & & & & & & $\begin{array}{l}\mathrm{i} \\
\mathrm{i}\end{array}$ & $\begin{array}{l}\text { Attend } \\
\text { toolbox } \\
\text { briefing }\end{array}$ & 3.4 \\
\hline & & & & & & & $\begin{array}{l}\mathrm{i} \\
\mathrm{i} \\
\mathrm{i}\end{array}$ & $\begin{array}{l}\text { Brief on } \\
\text { HIRARC \& } \\
\text { method } \\
\text { statement }\end{array}$ & 3.36 \\
\hline & & & & & & & $\begin{array}{l}\mathrm{i} \\
\mathrm{v}\end{array}$ & $\begin{array}{l}\text { Provide } \\
\text { PPE }\end{array}$ & 3.60 \\
\hline & & & & & & & $\mathrm{v}$ & $\begin{array}{l}\text { Provide fire } \\
\text { extinguisher }\end{array}$ & 3.46 \\
\hline \multirow[t]{2}{*}{6} & $\begin{array}{l}\text { Concrete } \\
\text { work }\end{array}$ & \multirow[t]{2}{*}{$\begin{array}{l}\text { Chemical } \\
\text { hazard }\end{array}$} & \multirow[t]{2}{*}{ Health } & \multirow[t]{2}{*}{6.40} & \multirow[t]{2}{*}{ High } & \multirow[t]{2}{*}{7} & $\mathrm{i}$ & $\begin{array}{l}\text { Use proper } \\
\text { PPE to } \\
\text { avoid } \\
\text { irritation } \\
\text { and } \\
\text { splashing }\end{array}$ & 2.90 \\
\hline & Control M & & & & & & $\begin{array}{l}\mathrm{i} \\
\mathrm{i}\end{array}$ & $\begin{array}{l}\text { Brief on } \\
\text { HIRARC \& } \\
\text { method } \\
\text { statement }\end{array}$ & 3.60 \\
\hline \multirow[t]{4}{*}{7} & \multirow{4}{*}{$\begin{array}{l}\text { Excavati } \\
\text { on of } \\
\text { pile cap }\end{array}$} & \multirow{4}{*}{$\begin{array}{l}\text { Landslide/s } \\
\text { heet pile } \\
\text { topple }\end{array}$} & \multirow[t]{4}{*}{ Safety } & \multirow[t]{4}{*}{9.86} & \multirow[t]{4}{*}{ High } & \multirow[t]{4}{*}{2} & $\mathrm{i}$ & $\begin{array}{l}\text { Machinery } \\
\text { inspection }\end{array}$ & 3.3 \\
\hline & & & & & & & $\begin{array}{l}\mathrm{i} \\
\mathrm{i}\end{array}$ & $\begin{array}{l}\text { Supervision } \\
\text { during } \\
\text { movement }\end{array}$ & 3.36 \\
\hline & & & & & & & $\begin{array}{l}\mathrm{i} \\
\mathrm{i} \\
\mathrm{i}\end{array}$ & $\begin{array}{l}\text { Competent } \\
\text { operator }\end{array}$ & 3.30 \\
\hline & & & & & & & $\begin{array}{l}\mathrm{i} \\
\mathrm{v}\end{array}$ & $\begin{array}{l}\text { Appoint } \\
\text { banksman }\end{array}$ & 3.46 \\
\hline
\end{tabular}

\section{CONCLUSIONS}

This risk assessment study has found that there were seven identified hazards during piling works of MRT project. One hazard had been assessed as extreme risk and other six hazards were high risks providing evidence that piling work for MRT construction was hazardous, risky and dangerous. For improving this hazardous situation, 27 risk control actions were conducted. All the control measures were rated as excellent actions with only 
one control act rated as good. These findings conclude that the MRT has taken an excellent risk control actions to counteract the perilous MRT construction site. Furthermore, this study also highlights HIRARC as a vital risk assessment tool that assist hazards identification, assessing the risk level and risk control measures with the purpose of eliminating or reducing the hazards of piling works at MRT construction project.

\section{ACKNOWLEDGEMENTS}

This study was supported by Ministry of Higher Education, Malaysia through Fundamental Research Grant Scheme (Ref: FRGS/1/2016/SSI11/UITM/03/1). The authors also would like to thank Universiti Teknologi MARA, Perak Branch and MRT staff for the assistance and opportunity to share these research findings in international conferences and publications.

\section{R E F E R E N C E S}

Ahmad, C. A, Zin, I. N. M., Wahid, A. M. A. \& Kamar, I. F. M. (2016), Hazard and risk of highway maintenance: case study of PLUS Expressways, In The $4^{\text {th }}$ International Building Control Conference 2016, MATEC Web of Conferences, 66 (106), 1-7.

Albert, A., Hallowell, M. R \& Kleiner, B. M. (2014) emerging strategies for construction safety \& health hazard recognition. Journal of Safety, Health \& Environment Research, 10 (2), 152-161.

Al-Kilani, F. M. (2011), Improving safety performance in construction projects in libya (case study: in Tripoli City): Master Thesis. Diponegoro University, Semarang, Indonesia.

Binnington, B. (2011) Managing risks in construction work draft code practice. Safe Work Australia, Australia.

Campbell, J. M. (2008) Safety hazard and risk identification and management in infrastructure management: doctoral dissertation. The University of Edinburgh, Scotland. https://www.era.lib.ed.ac.uk/handle/1842/3170

Carter, G. \& Smith, S. (2006) Safety hazard identification on construction projects. Journal of Construction Engineering and management, 132(2):197-205.

Chi, S. \& Han, S. (2013) Analyses of systems theory for construction accident prevention with specific reference to Osha accident reports. International Journal of Project Management, 31 (7), 1027-104.

Chong, H. Y. \& Low, T. S. (2014) Accidents in Malaysian construction industry: statistical data and court cases. International Journal of Occupational Safety and Ergonomics, 20 (3), 503-513.

Department of Occupational Safety and Health, Ministry of Human Resources Malaysia, (2008) Guidelines for Hazard Identification, Risk Assessment and Risk Control (HIRARC), Ministry of Human Resources, Malaysia, 6-12.

Fang, D. P., Xie, F, Huang, W. Y. \& Li, H. (2004) Factor Analysis-based Studies on Construction Workplace Safety Management in China. International Journal of Project Management, 22, 4349.

Goetsch, D. L. (2009) Construction Safety \& OSHA Standards. Prentice Hall, 89-90.

Guo, H. L., Li, H. \& Li, V. (2013) VP-Based Safety Management in Large-Scale Construction Projects: A Conceptual Framework, Automation in Construction, 34, 16-24.

Hamid, A. R. A., Yusuf, W. Z. W. \& Singh, B. (2003) Hazards at Construction Site, In Proceedings of the $5^{\text {th }}$ Asia Pacific Structural Engineering and Construction Conference (ASPEC). http://eprints.utm.my/445/

Health Safety Executive (2006), Risk Assessment: A Brief Guide to Controlling Risks in the Workplace. Health Safety Executive, U.K. 1-5.

Hinze, J. \& Raboud, P. (1988) Safety on large building construction projects. Journal of Construction Engineering and Management,114 (2), 286-293. 
Huges, P. \& Ferrett, E. (2008) Introduction to Safety and Health in Construction. Elsevier Ltd. 6880.

Kamar, I. F. M. \& Ahmad, C.A. (2016) A Conceptual Framework of Safety and Health in Construction Management, In The $4^{\text {th }}$ International Building Control Conference 2016, MATEC Web of Conferences, 66 (107), 1-9.

Lam, P. T. I., Chan, E. H. W., Poon, C. S., Chau, C.K. \& Chun, K. P. (2010) Factors affecting the implementation of green specification in construction. Journal of Environmental Management, 93 (3), 654-661.

MyMRT (2017) The MRT Sungai Buloh-Kajang Line. Retrieved from http://www.mymrt.com.my/en/sbk/travel-info

Perry, P. (2003) Construction Safety Question and Answer: A practical Approach. Thomas Telford LTD, Victoria, 181-190.

Ridley, J. R. (1990) Safety at Work. Third Edition. Butterworth Heinemann Ltd. 153-158

Stefanescu, L., Botezan, C. \& Craciun, L. (2018) Vulnerability Analysis for Two Accident Scenarios at An Upper-Tier Seveso Establishment in Romania. Geographia Technica, 13 (1), 109-118.

Welfare Health \& Safety Unit. (2015) Hazard Identification, Risk assessment and control procedure. Western Sydney University, Australia.

Work Safe Victoria. (2007) A Handbook for Workplaces-Controlling OHS Hazards and Risk, Victoria State Goverment. 